The Japanese Journal of Experimental

Social Psychology. 1984, Vol. 23, No. 2. 125-137

原

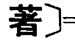

集団間関係ならびに個人・集団の達成度が 集団内・集団間の報酬分配に及ぼす効果 ${ }^{1)}$

\author{
九州大学 \\ 久木田純
}

\begin{abstract}
問
题

本研究は，自集団以外に他集団が存在し，課題を遂行 する状況において，集団間の友好性と達成度の高低およ び集団成員間の達成度の高低が，集団内之集団間の報酬 分配における各成員の公正感をどのように規定するのか を明らかにしょうとするものである。

「分配における公正」の問題は, Homans (1961) がそ
\end{abstract} の著書「Social Behavior」に拀いて，分配公正 (distributive justice) の概念を取り上げて以来, 社会心理 学の分野で数多くの研究がなされてきた。Adams(1965) は, この Homans の理論をさらに公平理論 (equity theory）へと展開させ，多くの実証的研究を生み出す基礎 を築いた。しかしその後の研究には, 公平理論の予測と は異なる結果もいくつか見出され (Morgan \& Sawyer, 1965; Leventhal, Michaels \& Sanford, 1972; Mikula, 1974; Lerner, 1974; Lam \& Schwinger, 1980) 多く の批判がなされるようになった。

その一つは, Sampson (1975), Deutsch (1975), Lerner (1975), Leventhal (1976) らが主張するように, 集団成員の達成度に相応して 分配するという公平 (equity）原理以外にも分配の公正汇影響を与元る原理がい くつか存在するというものであった。彼らは多くの分配 状況を整理し，そてで採用される諸原理がいかなるもの であるか，さらにどのような条件のもとでそれらの原理 が公正とされるかについて研究を進めてきた。

これらの諸研究を概観すると, 集団成員の志向と分配 原理の選択との間に強い結びつきが存在するてとを明ら かにしよとする試みが共通してみられる。特に共同場 面において最も多く採用される公平と平等の二つの原理 については前述の研究者の主張がほぼ斉合しており, 公 平原理との間に強い結びつきがあるてとは他の多くの研
究によって支持されている (Morgan \& Sawyer, 1965; Leventhal, Michaels \& Sanford, 1972; Reis \& Gruzen, 1976; Greenberg, 1977; Rosenbaum et al. 1980)。

さて，どのような状況のもとで公平原理と平等原理の 選択が行なわれるかについては，従来主として「共同で 課題達成を行ない，その結果得た報酬を集団成員間で分 配する」という実験パラダイムを用いた研究において検 討されてきた。しかし，集団の各成員が得る報酬量の点 から見ると、てのような状沉における公平原理または平 等原理の二者択一的採用は，新たに集団成員の達成度の 高低の要因が加わるととによってそれぞれ異なる意味を 持つようになる。

すなわち，達成度に応じて分配する公平原理の採用は， 達成度にかかわりなく均等に分配する平等原理を採用し た時よりも多くの報酬を高達成度の成員にもたらし，少 ない報酬を低達成度の成員にもたらす。

逆に平等原理の採用は公平原理の採用よりも多くの報 酬を低達成度の成員に，少ない報酬を高達成度の成員に もたらす。つまり，集団の得た一定量の報酬を分配する 状況においては，一方の報酬量が他方の報酬量を規定す る相互依存的な関係が生じるので，二つの分配原理のう ちどちらか一方を採用することは，高達成度の成員また は低達成度の成貝のうち一方にのみ有利な分配となるこ とを意味している。さらに，てのような相互依存的な関 係における集団成員に上万分配原理の選択は，他者から 見ると利己的または非利已的なものとして考えられる。

すなわち, 高達成度の成員が公平を選択することは利 己的であるのに対し，平等の選択は非利己的である。逆 低低成度の成員が公平を選択するてとは非利已的であ るのに対し, 平等の選択は利已的である。

ところで, このように一方のみに有利または不利にな

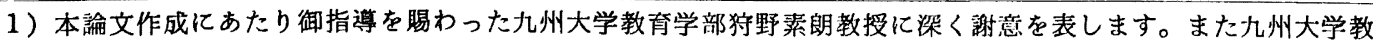
育学部原田純治助手には数多くの御示唆をいただきました。とてに記して感謝いたします。 


\section{実験社会心理学研究 第23巻 第 2 号}

る分配原理を他成員が選択することは，集団成貝間の好 ましい関係や連帯を弱めるものであろう。このととは, 集団成員の連帯志向と平等原理の 選択という Morgan \& Sawyer (1967), Sampson (1975), Deutsch ら (1975) の主張とは斉合しない。集団内の対人関係を良好にし連 帯を強めるのであれば, 高達成度の成員と低達成度の成 員が相互に非利己的な分配原理の選択をするととが必要 だと予測される。

Mikula (1974) の研究は乙の仮定を支持している。彼 によると,オーストリアに留学中のアメリカ人学生を被 験者とした分配では, 異国で共に協同生活を体験したた めに彼らの相互依存性と連帯感が強まり, 高達成度の成 員は平等分配を, 低達成度の成員は公平分配を選択し, 相互に非利己的な分配を行なったという結果が得られて いる。

Valentine (1971) も集団内の連帯性之相互依存性を 高める操作によって, 被験者が互いに非利己的な分配を 行なったという結果を得ている。さらに Shapiro (1975), Reis \& Gruzen (1976)，松崎，上野ら（1980）の自己 呈示（self-presentation）之報酬分配に関する一連の研 究も, 他者からの社会的承認を得るために高達成度の成 員と低達成度の成員が互いに非利已的な分配の方略をと ったてとを示している。以上のような結果に加え，非利 己的な選択を行なう宽容な分配者に対して, 被験者が好 意を示した Kahn, Lamm \& Nelson (1977), Feather \& O'driscoll (1980), Watts \& Messé (1982), Greenberg ら (1982) の一連の研究の結果加らも集団成員間 の好ましい対人関係や連帯は, 集団内の平等分配之直接 結びつく前に，まず各集団成員の非利已的分配原理の選 択と強く結びついているものと思われる。

このように見てくると, Morgan \& Sawyer (1967), Deutsch (1975), Sampson (1975) らの主張には, 個人 による意志決定から集団による意志決定への過程に関す る分析が落していることが考えられる。つまり, 強い 連带感をもった各集団成員が相互に非利已的な選択を行 なった後に, 公平と平等の雨分配原理のうちどちらを集 団内の分配において採用するのかという過程についてさ らに明らかにする必要があると思われる。

Shapiro (1975), Leventhal ら (1975) は, 分配原理 選択についての個人決定と集団決定には重要な違いがあ ることを指摘している。つまり達成度の異なる成員は個 人決定において異なる選択を行なっていることが考えら れるが，集団決定においては，影響力の強いどちらか一 方の決定が採用されることになるからである（Kahn， Nelson, Gaeddert, \& Hearn, 1982)。
以上のととから，前述の集団成員間の連帯と平等原理 の選択とを結びつける主張には，乙れらの結びつきに到 るプロセスにおいて，集団成員相互の非利己的分配原理 の選択と集団意志決定時の高達成度の成員と低達成度の 成員による相互の影響過程の存在が加えられねばならな いであろうと予測される。

さらに，その場合集団決定において平等原理が選択さ れるのであれば, 高達成度の成員による強い影響力があ るものと予測される。

利己的・非利已的分配原理の選択という以上のような 視点から最近の知見を分析すると, 例えば相川 (1981) は, 未知の他者間の分配と友人間の分配という二つの条 件下での個人決定と集団決定における報酬分配について 検討し, 友人条件下の個人決定において高寄与率の成員 と低寄与率の成員が相互に非利己的選択を行ない, 非対 面状況で行なった集団決定においては平等分配で合意さ れたという結果を得ている。また他人条件下では個人決 定において相互に非利己的選択が行なわれたが, 集団決 定では公平分配で合意がなされたとの結果も得ている。 てれらの結果は, 連帯性の強い友人間では平等, 経済志 向性の強い他人どうしでは公平という従来の研究結果を 支持すると共に，協同場面における集団内での報酬分配 原理選択過程に関する先の仮定を支持するものである。 本論文における問題提起の一つは, 分配公正に関する研 究結果を以上のように利己的・非利已的分配原理の選択 という視点から検討することにある。

さて，現実場面において集団は他の集団之相互依存的 関係にあるととが多く, 複数の集団から成る学校や会社 などの組織においては集団内分配のみならず集団間分配 の問題も数多く生起している。従って集団間の分配はそ れ自体重要な問題として取り扱われるべきであろう。

また，集団の外的環境としての集団間分配に関する研 究は, 自集団の枠組を通して個人が他集団にどのように 儌きかけ，かつどのような影牟を他集団から受けるのか についての過程を明らかにする一つの有効なアプローチ としても重要であると思われる。

しかし，従来の分配公正に関する研究は二者間または 集団内部での報酬分配を中心に検討されており，集団間 の分配について検討されてきたものは少ない(Commins \& Lockwood, 1979; Sik, 1981)。

さらに，他集団との報酬分配が集団内の分配にどのよ うな影㹕をおよほすすのかてつての知兒はほとんど見ら れない (Rabbie et al., 1974)。

そてで, 本研究においては従来の集団内分配の問題に 加え集団間分配の問題を取り上げ，先に問題提起した利 
久木田 : 集団間関係ならびに個人・集団の達成度が集団内・集団間の報酬分配に及ぼす効果

己的・非利已的分配原理の選択の視点から分析を行なわ たい。

集団間分配に関する問題の一つは，集団内分配に関す ろ従来の知見が集団間分配の状況においてもあてはまる かどうかである。

Sampson (1975), Deutsch (1975), Lerner (1975), Leventhal (1975)，相川ら (1981) の集団内分配関す る予測が集団間分配においてあてはまるならば，前述の ような実験パラダイムにおいて, 集団間が他人の関係で ある時には公平原理の選択が公正であり, 集団間が友好 的である時には平等原理の選択が公正であると評価され る傾向が見られるものと予測される。

さらに，集団内分配において見られたように，集団間 分配においても相手集団との相互作用が強く予期される 状況では被験者の肯定的な自己呈示 (self-presentation) への欲求が見られ，利己的な分配原理の選択は弱まるも のと思われる (Shapiro; 1974)。すなわち，他集団に自 集団の選択を呈示する決定である集団決定においては, 他集団に提示されるてとのない個人決定においてよりも 非利己的な分配原理の選択がなされるものと予測される。

集団間分配に関するもう一つの問題は，他集団との分 配という集団の外的要因が集団内の分配にどのように影 響するかである。

Rabbie et al. (1974) によると，集団間が競争的で非 友好的な関係にある条件では, 取引上強い立場の集団に おいては，弱い立場の集団に扔てよりも凝集性が高ま り，逆に集団間が協同的で友好的な関係にある条件では 取引上弱い立場の集団において凝集性が高まったという 結果が報告されており，集団間の要因が集団内の成員間 関係に影響を及ぼすことが考えられる。

すなわち，非友好的な外集団が存在する条件において は，達成度の高い集団内で，より非利己的な分配原理選 択がなされる傾向があると予測される。逆に集団間の関 係が友好的である条件においては達成度の低い集団内で, より非利己的な分配原理選択がなされる傾向があると予 測される。以上のような点から本研究では，集団内・集 団間分配に扔ける分配公正の問題を利己的・非利已的分 配原理選択の锖点から分析することとし，集団間の関係 が友好的である場合を実颐 I , 非友好的である場合を II として検討する。

\section{実 験 I}

方法

集団内，集団間の関係がともに友好的である場合に， 成員間, 集団間の課題達成度の高低が集団内分配, 集団
間分配での各成員の分配公正をどのように規定するかを 検討する。なお，集団成員間，集団間の友好性について は, 現実の友人集団から一度に 4 人の被験者を抽出し, 4 条件にふりわけるとともに，貿問紙によって互いに一 定の好感情を持つように統制された。

\section{<被験者 $>$}

被験者は大学生男女計40名が, 現実の友人集団から 4 人ずつ抽出され， $2 \times 2$ 条件に 10 グループずつ（男女各 5 グループ）無作為に割当てられたが，実験に疑いた持 った者が所属する 2 集団（4名）のデータが削除され， それぞれの条件のもとで新しいデータが補充された。

\section{$<$ 実験計画 $>$}

実験は，独立変数として，(1) 集団の課題達成度の高 低 (High-Low Group Performance, 以下各 HG, LG 之略す)，(2) 集団成員の課題達成度の高低 (High-Low Individual Performance, 以下 $\mathrm{H}, \mathrm{L}$ 之略す) を用い, $2(\mathrm{HG}, \mathrm{LG}) \times 2(\mathrm{H}, \mathrm{L})$ の要因計画で行なわれた。

\section{<独立変数の操作 $>$}

\section{（1）集団成員の達成度の高低}

各成員の達成度は, 課題達成後の得点報告において操 作され, 高達成度の成員 $(\mathrm{H})$ と低達成度の成員 (L)の各 試行における達成度の比率が約 $6: 4.5$ 亿なるように実 験者によってあらかじめ決められた得点が告げられた。 3 試行の合計得点は, 高達成度成員と低達成度成員がそ れぞれ603点と466点であった。

\section{（2）集団達成度の高低}

各集団の達成度の高低も, 課題達成後の得点報告にお いて操作されたが，高達成度集団（HG）は他集団が低 得点であると報告されることによって高達成度であると 認知し，低達成度集団 (LG) は他集団が高得点であると 報告されることによって低達成度であると認知するよう 操作された。すなわち 3 試行の合計得点は, 各集団とも HとLがそれぞれ603点と466点で計1，069点であったが， HG には他集団の $\mathrm{H} か ゙ 477$ 点， Lが452点で計929点であ つたと報告され，LG には他集団のHが614点，Lが588 点で計1,202点であったと報告された。

\section{<手続き>}

（1） 4 人の被験者は実験室入室後 Fig. 1 のように 着席し, 実験の目的（産業場面のシミュレーションに関 する実験であると伝えられた)，公平と平等の二つの分 配原理，マークシート課題（配布されたデータに従って， コンピュータ・カードの数字を染りつぶす）についての 教示をうけた。次に練習武行 1 回を行なった後、マーク ・シートの採点法と報酬（1点を 1 円とし，4人の総合 


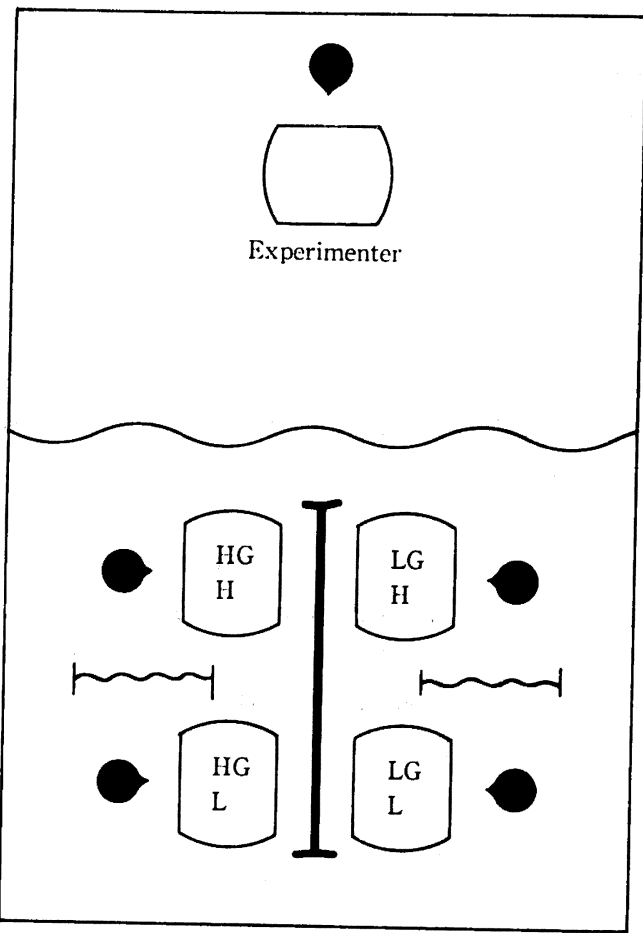

Fig. 1. Location of the subjects and setting of the laboratory.

得点に対し報酬が支払われると伝えられた）についての 説明および各分配原理の理解についての質問紙によるチ エックを受け，本試行に入る。

（2）本武行では，3 回の試行とともに達成度の操作 と劕問紙の回答が次のように行なわれた。

(a) 第 1 武行: 3 分30秒のマーク・シート作業後, 実験助手による採点（別室において，カードパンチャー を用いて行なわれると伝えられた）が行なわれ，その間 集団内の相手に対する友好性についての質問紙（7段階 評定尺度）に回答した。次にての質問紙（あらかじめ実 験者によって互いに好感情を持ち集団凝集性が高まるよ うに統制されたものを相手が記入したとして手渡され た）を交换した後，4人の被䀦者全員の課題達成度（集 団内達成度の高・低と集団間達成度の高・低について各 条件ごとに操作されたもの）を記入した用紙がー枚ずつ 手渡された。

(b) 第 2 武行: 3 分 30 秒のマーク・シート作業後, 採点が行なわれ，その間他集団に対する友好性について の質問紙に回答した。次にての質問紙（集団間の友好性 を高めるため実験者によってあらかじめ操作され，すり かえられたもの）を集団相互で交換した後, 第 2 試行で
の 4 人の課題達成度（各条件ごとに操作されたもの）を 第 1 武行のものとあわせて表記した用紙が手渡された。

(c) 第 3 試行： 3 分30秒のマーク・シート作業後, 採点が行なわれ，その間第 1 , 第 2 試行で行なった集団 内・集団間友好性操作のチェックを行なう質問紙に回答 した。次に 3 回の試行における達成度を, 個人, 集団, 全体の合計についてそれぞれ記入したものが各被験者に 手渡された。

（3）従属変数の測定

（a）個人決定状況において, 集団内・集団間分配原 理の選択（各被験者が選択した原理を紙片に記入し実験 者に手渡した）と各分配原理を採用することへの公正感 の評定（公正である，不公正である，を対とした 7 段階 評定尺度）が行なわれ，補足的な筫問項目（集団内の他 者および他集団が各分配原理をどの程度好ましいと思っ ているか)にいいての回答がなされた。

（b）個人決定後二者間のスクリーンがとりのぞかれ， 集団成員間の討議による 集団決定状況において,「集団 内の分配方式について 2 人で納得がいくよう話し合って, 公平か平等のどちらかを選択して下さい」という教示が 行なわれ，集団内分配原理の決定と補足的な 質問項目 （决定への高得点者と 低得点者の影響度）への回答がな された。次に，「集団間の討議を行なう前に，集団間分 配での分配方式について 2 人でよく話し合って決めて下 さい」という教示が行なわれ, 集団決定状況における集 団間分配原理の選択と補足的な質問項目（決定への高得 点者と低得点者の影響度) への回答がなされた。

集団決定後, 集団内, 集団間の達成度操作をチェック する筫問紙への回答がなされたのち，被験者全員に達成 度の操作之集団内, 集団間の友好性の操作を行なったて 上および本実験の真の目的について説明をし，十分な 了承を得た後, 各被験者に実験参加の謝金が一率に(500 円）支払われ，実倹を修了した。

$$
\text { 結果 }
$$

\section{〈操作チェック>}

自己および自集団の達成度の高低についてすへての被 験者が操作通り認知していた。また, 公平原理と平等原 理による報酬分配の違いについても，すべての被䀦者が 教示通り認知していたてとが明らかであった。さらに, 集団内の他成員之相手集団への好意度の評定値について 分散分析を行なった結果, 好意度, 集団達成度, (HG, $\mathrm{LG})$, 個人達成度，(H, L) の間に主效果および交互作

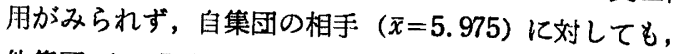
他集団 $(\bar{x}=5.875)$ に対しても等しく好意的 $(F(1.36)$ 
$=0.305, \mathrm{~N} . \mathrm{S})$ であったてとが明らかであった。

＜個人決定による分配原理の選択と評定〉

Table 1 は集団内分配原理として公平と平等のいずれ かを選択した被験者の数を条件ごとに示したものである。 対数一線型モデルの当てはめ2) による分析の結果, 分配 原理 (equity, equality) の主効果 $\left(\hat{u}_{3}=0.499, S E=\right.$ $0.218, p<.05)$ および個人達成度と分配原理の選択の 交互作用 $\left(\hat{u}_{23}=0.599, S E=0.218, p<.01\right)$ が有意で あった。すなわち, この二つの結果から集団内分配にお いては, 平等原理が公平原理に比べて多く選択されたが, 成員の達成度によって選択が異なり，HはLよりも平等 を多く選択し，LはHよりも公平を多く選択したてとが 見出された。また, 各分配原理の公正度の評定值に関し $\tau(H G, L G) \times(H, L) \times($ Equity, Equality) の分散 分析を行なった結果, 個人達成度と分配原理の交互作用 のみに傾向 $(F(1,36)=3.967 ， p<.10)$ が見られた。

Table 2 は集団間分配原理として公平と平等のいずれ かを選択した被験者の数を各条件ごとに示したものであ る。対数一線型モデルの当てはめによろ分析の結果, 分 配原理選択の主効果 $\left(\hat{u}_{3}=0.469, S E=0.189, p<.05\right)$ のみが有意であった。すなわち，集団間分配原理として 公平よりも平等が多く選択されたてとが見出された。各 分配原理の評定值については, 有意な結果は見出されな かった。集団内の他者および他集団が各分配原理をどの

Table 1

The number of subjects who chose either equity or equality as an intragroup distribu. tion principle in Exp. I.

\begin{tabular}{lcccc}
\hline & \multicolumn{3}{c}{ Level of performance } \\
\cline { 2 - 5 } Principle & \multicolumn{3}{c}{ HG } & \multicolumn{3}{c}{ LG } \\
\cline { 2 - 5 } & H & L & H & L \\
\hline Equity & 1 & 4 & 1 & 7 \\
Equality & 9 & 6 & 9 & 3 \\
\hline
\end{tabular}

Table 2

The number of subjects who chose either equity as an intergroup distribution principle in. Exp. I.

\begin{tabular}{lccccc}
\hline & \multicolumn{4}{c}{ Level of performance } \\
\cline { 2 - 5 } Principle & \multicolumn{3}{c}{ HG } & \multicolumn{3}{c}{ LG } \\
\cline { 2 - 5 } & H & L & H & L \\
\hline Equity & 2 & 2 & 2 & 6 \\
Equality & 8 & 8 & 8 & 4 \\
\hline
\end{tabular}

程度好ましいと思っているかについての評定值の平均を 各条件ごとに示したのが Fig. 2，3である。これにつ いて, 集団内分配, 集団間分配別に (HG, LG) $\times(H$, L) $\times$ (Equity，Equality) の分散分析を行なった。集団 内分配においては何ら有意な結果は見出されなかった

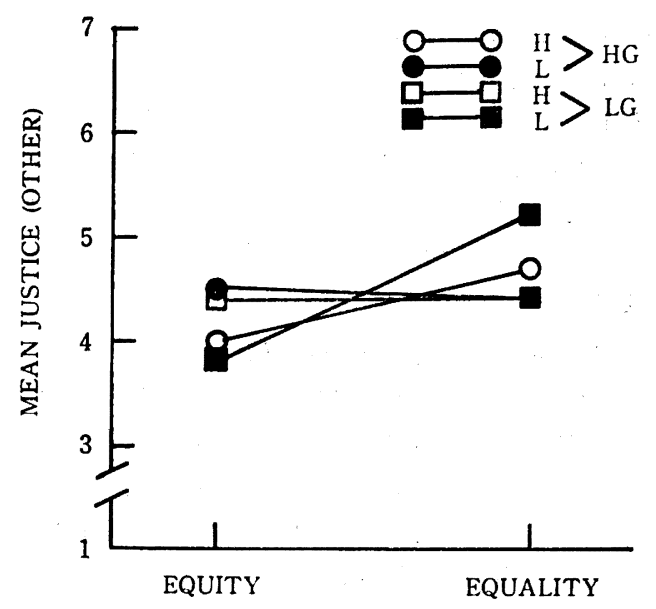

Fig. 2. Mean of justice evaluation of how the partner would evaluate equity and equality as an intragroup distribution principle in Exp. I.

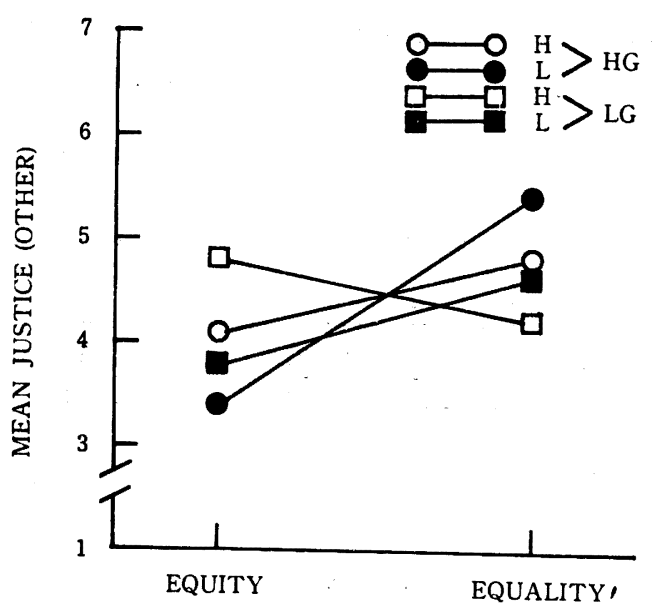

Fig. 3. Mean of justice evaluation of how the members of the other group would evaluate equity and equality as an intergroup distribution principle in Exp. I.

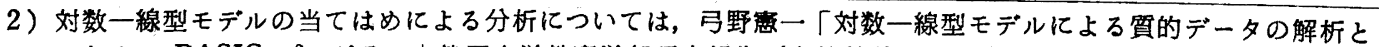
そのための BASIC プログラム」静岡大学教育学部研究報告 (自然科学篇) 第32号 (1981) のうち LOG3のプ ログラムを使用させていただいた。なお，有意水準は $\hat{u} の$ 值を $S E$ の值で割った $z$ の值によって求められた。 
が，集団間分配において分配原理の主効果 $(F(1,36)=$ $4.256, p<.05)$ および個人達成度と分配原理の評定の 交互作用 $(F(1,36)=4.256, p<.05)$ が有意であった。 単純効果検定の結果，Lにおける分配原理の評定に有意 な差 $(F(1,36)=7.914, p<.01)$ が見られた。また, 集団達成度と分配原理 の評定の交互作用に傾向（F $(1,36)=3.669, p<.1)$ が見られ，単純効果検定の結果， HG における分配原理の評定に有意な差 $(F(1,36)=$ 8.511，p<.01）が見られた。すなわち，集団間分配に おいて他集団が公平原理よりも平等原理を好ましいと思 っていると被験者は認知しており，LはHよりも，また HG は LG よりも他集団が平等原理を好ましいと思って いると認知したことが見出された。

\section{＜集団決定による分配原理の選択＞}

Table 3 は集団内分配, 集団間分配での各集団の分配 原理選択を示したものである。すなわち，集団内分配， 集団間分配のいずれにおいても公平原理よりも平等原理 が多く選択された。次に，集団内分配において平等原理 を選択した集団における集団決定への $\mathrm{H}$ と L の影響度の 自己評定について，(HG，LG) $\times(H ， L)$ の分散分析を 行なった結果，交互作用 $((F 1,34)=3.080, p<.10)$ に傾向がみられた。単純効果の検定を行なった結果, $\mathrm{HG}$ におけるH とLの間に有意差 $(F(1,34)=4.549$, $p<.05 ）$ が見られた。すなわち，集団内分配において平 等原理を選択した高達成度集団においては, 高達成度の 成員が低達成度の成員よりも強く決定に影響したてとが 見出された。

Table 3

The number of dyads which chose either equity or equalty as an intra- and inter-group distribution principle in Exp. I.

\begin{tabular}{lcccc}
\hline \multirow{2}{*}{ Principle } & \multicolumn{2}{c}{ Intragroup } & \multicolumn{2}{c}{ Intergroup } \\
\cline { 2 - 5 } & HG & LG & HG & LG \\
\hline Equity & 1 & 0 & 2 & 2 \\
Equality & 9 & 10 & 8 & 8 \\
\hline
\end{tabular}

実験 II

方法

集団内の関係は友好的であるが集団間の関係が非友好 的である場合に, 成員間と集団間の課題達成度の高低が 集団内分配, 集団間分配での各成員の分配公正をどのよ うに規定するかを検討する。なお集団成員間，集団間の 友好性については，現実の友人集団から 2 人ずつ抽出し， 互いに見知らぬ 2 集団を組み合わせた後, 集団内の友人
間では友好性を高める方向に，集団間では友好性を低め る方向に質問紙による操作がなされた。

\section{<被験者>}

被験者は大学生男女計 40 名が現実の友人集団から 2 人 ずつ20組抽出され， $2 \times 2$ 条件に10グループずつ（男女 各 5 グループ）無作為に割当てられたが，質問紙への記 入が不完全であった者が所属する 2 集団（4名）のデー タが削除され，それぞれの条件のもとで新しいデータが 補充された。

\section{$<$ 実験計画 $>$}

実験 $\mathrm{I}$ と同じ独立変数を用い, $2(\mathrm{HG}, \mathrm{LG}) \times 2(\mathrm{H}, \mathrm{L})$ の要因計画で行なわれた。

\section{<独立变数の操作>}

集団成員の達成度の高低, 集団達成度の高低の操作は ともに実験 I と同じ操作が行なわれた。

\section{<手続き>}

実験I と同じ手続きを用いた。ただし，第 2 試行に交 換した相手集団に関する質問紙について実験 IIでは，集 団間の友好性を低める方向に操作されたものが用いられ た。

結果

\section{〈操作チェック>}

自己および自集団の達成度の高低についてすべての被 験者が操作通りに認知していた。また, 公平原理と平等 原理による報酬分配の違いについても，すへての被験者 が教示通り認知していたてとが明らかであった。さらに, 集団内の他成員之相手集団への好意度の評定值について (集団内の他成員之相手集団への好意度 $) \times($ HG, LG $) \times$ (H, L) の分散分析を行なった結果，(集団内の他成員之 相手集団への好意度）の主効果 $(F(1,36)=132.719$, $p<.01)$ のみが有意であり, 集団内の成員間では友好的 $(\bar{x}=5.85)$ であるのに対し，集団間では非友好的（ $\bar{x}=$ 3.85)であったてとが明らかであった。

\section{＜個人決定による分配原理の選択と評定>}

Table 4 は集団内分配原理として公平と平等のいずれ

Table 4

The number of subjects who chose either equity or equality as an intragroup distribu. tion principle in Exp. II.

\begin{tabular}{lcccc}
\hline & \multicolumn{3}{c}{ Level of performance } \\
\cline { 2 - 5 } Principle & \multicolumn{3}{c}{ HG } & \multicolumn{3}{c}{ LG } \\
\cline { 2 - 5 } & H & L & H & L \\
\hline Equity & 1 & 7 & 1 & 9 \\
Equality & 9 & 3 & 9 & 1 \\
\hline
\end{tabular}




\section{久木田：集団間関係ならびに個人・集団の達成度が集団內・集団間の報酬分配に及ぼす効果}

かを選択した被験者の数を条件ごとに示したものである。 対数一線型モデルの当てはめによろ行析の結果, 個人達 成度之 分配原理の. 選択の 交互作用 $\left(\hat{u}_{23}=0.930, S E=\right.$ $0.244, p<.01)$ が有意であった。すなわち，集団内分 配においては成員の達成度によって選択が異なり，Hは Lよりも平等を多く選択し， LはHよりも公平を多く選 択したことが見出された。各分配原理の公正度評定の平 均值を各条件ごとに示したのが Fig. 4 である。Fig. 4 について (HG, LG) $\times(H, L) \times($ equity, equality) 分散分析を行なった結果，分配原理の主効果 $(F(1,36)$ $=5.331 ， p<.05)$ および個人達成度と分配原理の評定 の交互作用 $(F(1,36)=24.198, p<.01)$ が有意であっ た。この交互作用につき，単純効果の検定を行なった結 果, equity の評定における $\mathrm{H}$, L 間, equality の評定 における $\mathrm{H}, \mathrm{L}$ 間にそれぞれ $(F(1,36)=13.134, p$ $<.01),(F(1,36)=16.783, p<.01)$ 有意差がみられ， また, Lの equity と equality の評定においても有意 差 $(F(1,36)=29.123, p<.01)$ がみられた。すなわち 集団内分配においては公平原理がより高く評価されたが, $\mathrm{H}$ と L の評定が公平と平等では異なり，HはLよりも公 平を高く評価したことが見出された。

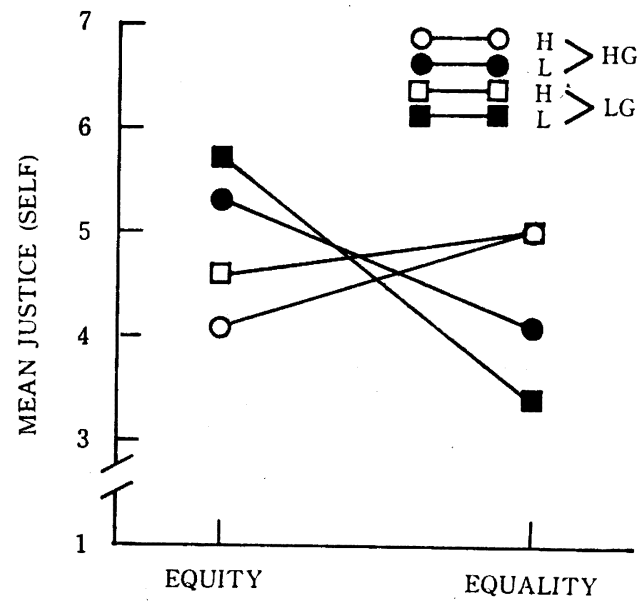

Fig. 4. Mean of justice evaluation of equity and equality as an intragroup distribution principle in Exp. II.

Table 5 は，集団間分配原理として公平と平等のいず れかを選択した被験者の数を各条件ごとに示したもので ある。対数一線型モデルの当てはめによろ分析の結果, 分配原理の主効果 $\left(\hat{U}_{3}=0.482, S E=0.194, p<.05\right)$ が有意であった。すなわち，集団間分配原理として公平 が多く選択されたことが見出された。各分配原理の公正
Table 5

The number of subjects who chose either equity or equlity as an intergroup distribu. tion principle in Exp. II.

\begin{tabular}{lcccc}
\hline & \multicolumn{4}{c}{ Level of performance } \\
\cline { 2 - 6 } Principle & \multicolumn{3}{c}{ HG } & \multicolumn{3}{c}{ LG } \\
\cline { 2 - 5 } & H & L & H & L \\
\hline Equity & 6 & 6 & 7 & 9 \\
Equality & 4 & 4 & 3 & 1 \\
\hline
\end{tabular}

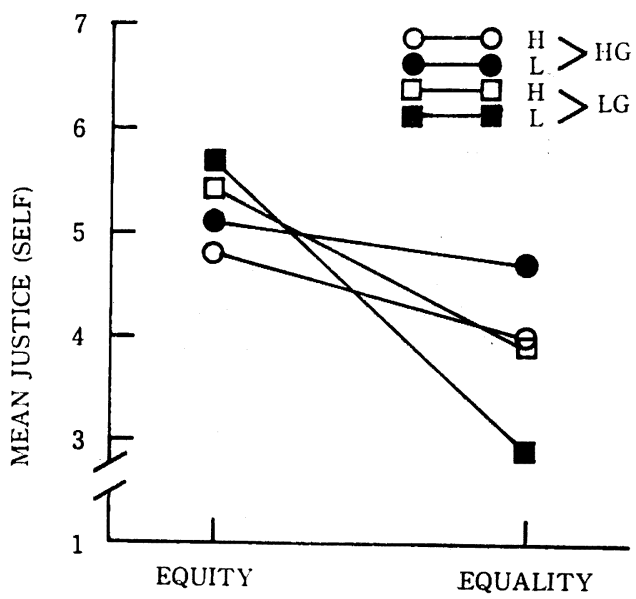

Fig. 5. Mean of justice evaluation of equity and equality as an intergroup distribution principle in Exp. II.

度評定の平均值を条件ごとに示したのがFig. 5 である。 Fig. 5 について (HG, LG) $\times(\mathrm{H}, \mathrm{L}) \times$ (eguity, equa. lity）の分散分析を行なった結果，分配原理の評定の主 効果 $(F(1,36)=19.159 ， p<.01)$ と集団達成度と分配 原理の評定の交互作用 $(F(1,36)=1.087, p<.05)$ ，お よび集団達成度と 個人達成度の 交互作用 $(F(1,36)=$ $5.031, p<.05)$ が有意であった。集団達成度と分配原 理の評定の交互作用について単純効果の検定を行なった 結果, eguity の評定において HG と LG の間に有意 差 $(F(1,36)=6.706, p<.01)$ がみられ，また LG に おける eguity と equality の評定の間にも有意差 ( $F$ $(1.36)=23.422, p<.01)$ が見られた。すなわち, 集団 間分配においては, eguity の評価が高かったが, equity の評価において LG よりも HG が高い評価をし， LG は equalityよりも equity を高く評価したことが見出 された。

集団内の他者および他集団が各分配原理をどの程度好 ましいと思っているかについての評定值の平均を各条件 ごとに示したのが Fig. 6,7である。これについて，集 


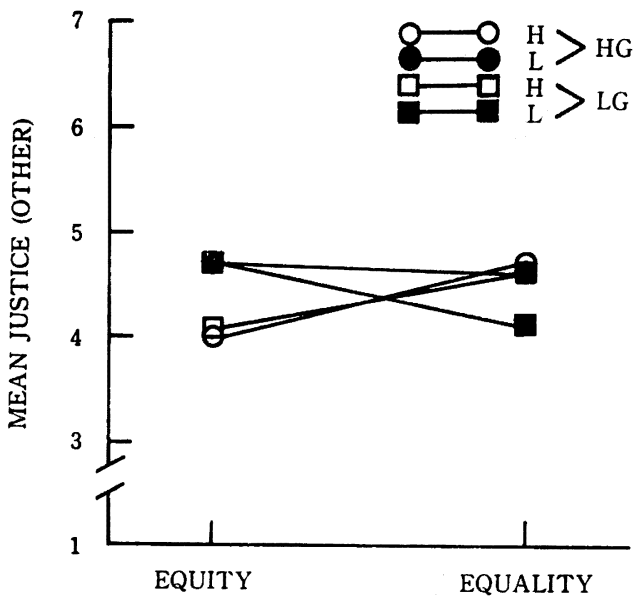

Fig. 6. Mean of justice evaluation of how the partner would evaluate equity and equality as an intragroup distribution principle in Exp. II.

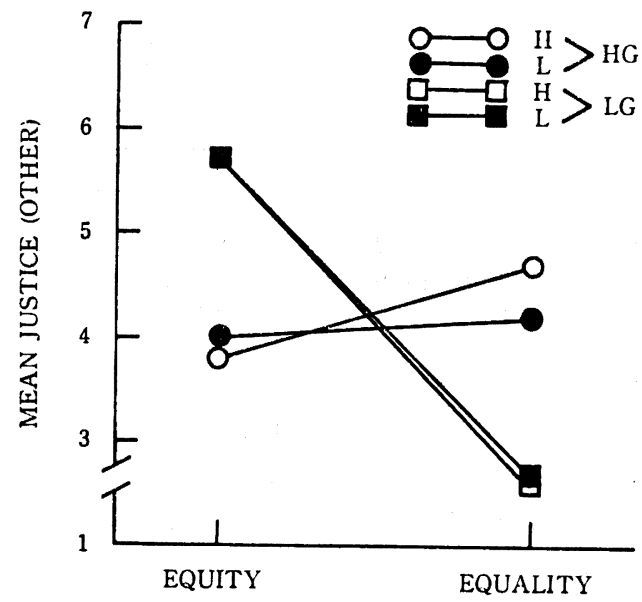

Fig. 7. Mean of justice evaluation of how the members of the other group would evaluate equity and equality as an intergroup distribution prin. ciple inExp. II.

団内分配, 集団間分配別に $(H G, L G) \times(H, L) \times(e q$. uity, equality）の分散分析を行なった。集団内分配に おいては何ら有意な結果は見出されなかったが, 集団間 分配に扔いて分配原理の主効果 $(F(1,36)=15.690, p$ <.01）および集団達成度と 分配原理の評定の 交互作用 ( $\mathrm{F}(\quad(F(1,36)=32.536, p<.01)$ が有意であった。単 純効果検定の結果, equity の評定之 equality の評定に おける HG と LG 間に有意差（それぞれ， $F(1,36)=$ $28.449, p<.01$, と $F(1,36)=28.449, p<.01)$ が見
られ，また LG における equity と equality の評定間 にも有意差 $(F(1,36)=76.707, p<.01)$ が見られた。 すなわち, 集団間分配において他集団が平等原理よりも 公平原理を好ましいと思っていると被験者は認知してお り, LG は HG よりも相手集団が公平原理を, 逆に HG は LG よりも相手集団が平等原理をそれぞれ好ましい と認知したことが見出された。また，LG においては， 相手集団が平等原理よりも公平原理を好ましいと思って いると認知したことが見出された。

\section{＜集団決定による分配原理の選択>}

Table 6 は集団内分配, 集団間分配での各集団の分配 原理選択を示したものである。 $x^{2}$ 検定の結果 $\mathrm{HG}$ と LG の分配原理の選拒が集団内分配 $\left(x^{2}=5.495, d f=\right.$ $1, p<.02)$, 集団間分配 $\left(x^{2}=7.50, d f=1, p<.01\right)$ のそれぞれにおいて有意に異なっていた。すなわち，集 団内分配, 集団間分配のいずれにおいても HG は LG よりも平等原理を多く選択し, LG は HGよりも公平原 理を多く選択したととが見出された。次に，集団内分配 において 平等原理を 選択した 集団における 集団決定へ のH と Lの 影響度の 自己評定について，(HG，LG) $\times$ (H, L) の分散分析を行なった結果，個人達成度の主効 果 $(F(1,22)=5.945, p<.05)$ のみに有意差がみられた。 すなわち，集団内分配において平等原理を選択した集団 においては高達成度の成員 $(\bar{x}=5.077, S D=1.115)$ が 低達成度の成員 $(\bar{x}=4.077, S D=1.441)$ よりも強く決 定に影響したと羿知していたととが見出された。

Table 6

The number of dyads which chose either equity or equality as an intra- and an inter. group distribution principle in Exp. II

\begin{tabular}{lcccc}
\hline \multirow{2}{*}{ Principle } & \multicolumn{2}{c}{ Intragroup } & \multicolumn{2}{c}{ Intergroup } \\
\cline { 2 - 5 } & HG & LG & HG & LG \\
\cline { 2 - 5 } Equity & 1 & 6 & 3 & 9 \\
Equality & 9 & 4 & 7 & 1 \\
\hline
\end{tabular}

\section{実験 I と実験 II の結果の総合的比交}

実験 I と実験 II の相違点は集団間の友好性の程度の違 いであった。ここでは両実験の結果を総合的に比較する ために, 集団間の友好性を一つの要因とみなし，個人決 定による集団内・集団間分配原理の選択および集団決定 による集団内・集団間分配原理の選択について分析を行 なう。

＜個人決定による分配原理の選択＞

実験 I と実験 Iにおける，個人決定による 集団内分 配原理の選択について 各分配原理ごとに対数一線型モ 


\section{久木田：集団間関係ならびに個人・集団の達成度が集団内・集団間の報酬分配に及ぼす効果}

デルの あてはめによる（集団間友好性） $\times(H G, ~ L G) \times$ $(H, L)$ の分析を行なった結果, 個人達成度の主効果が equity 選択 ( $\left.\hat{u}_{3}=0.934, S E=0.369, p<.01\right)$ と equality 選択 $\left(\hat{u}_{3}=0.600, S E=0.189, p<.01\right)$ の両方にみ られた。すなわち，集団内分配についての個人决定にお いては，HがLよりも平等原理を多く選択し，LがHよ りも公平原理を多く選択したてとが見出された。

次に個人決定に上る集団間分配原理の選択について各 分配原理ごとに対数一線型モデルのあてはめによる（集 団間友好性 $) \times(H G, L G) \times(H, L)$ の分析を行なった結 果, 集団間友好性の主効果が equity 選択 $\left(\hat{u}_{1}=0.482\right.$, $S E=0.188, p<.05)$ と equality の選択 $\left(\hat{u}_{1}=0.469\right.$, $S E=0.196 ， p<.05)$ の両方にみられた。すなわち集団 間分配についての個人決定では, 集団間が非友好的な状 況よりも集団間が友好的な状況において平等原理が多く 選択され，逆に集団間が友好的な状況よりも集団間が非 友好的な状況において公平原理が多く選択されたてとが 見出された。

\section{＜集団決定による分配原理の選択＞}

Table 3 と Table 6 の集団内分配について（集団間 友好性) $\times($ HG, LG) $\times$ (equity, equality) の対数一線 型モデルのあてはめによる分析を行なった結果，分配原 理選択の主効果 $\left(\hat{u}_{3}=0.796, S E=0.450, p<.01\right)$ が有 意であった。また，集団間友好性と分配原理の選択の交 互作用 $\left(\hat{u}_{3}=0.427, S E=0.250, p<.10\right)$ および集団間 友好性, 集団達成度と分配原理の選択の交互作用 $\left(\hat{u}_{123}\right.$ $=0.427, S E=0.250, p<.10 ）$ 亿傾向が見られた。

すなわち, 集団内分配においては平等原理が公平原理 よりも多く選択されたてとが明らかであったが，集団間 が友好的な状況よりも集団間が非友好的な状況において 公平原理が多く選択され，集団間が非友好的な状況の LG においては他の条件においてよりも公平原理が多く 選択される傾向にあったてとが見出された。

次に, Table 3 と Table 6 の集団間分配について, (集団間友好性) $\times(\mathrm{HG}, \mathrm{LG}) \times$ (equity, equality) の対 数一線型モデルのあてはめに上る分析を行なった結果， 集団間友好性と分配原理の選択の交互作用 $\left(\hat{u}_{13}=0.515\right.$, $S E=0.211 ， p<.05)$ が有意であった。また，集団達成 度と分配原理の選択の交互作用 $\left(\hat{u}_{23}=0.381, S E=0.211\right.$, $p<.10)$ および集団間友好性，集団達成度之分配原理の 選択の交互作用 $\left(\hat{u}_{123}=0.381, S E=0.211, p<.10\right)$ に 傾向がみられた。すなわち，集団間が友好的な状況では 公平上りも平等が多く選択されたが，集団間が非友好的 な状況では平等より公平が多く選択されたてとが見出さ れた。また, HG は公平よりも平等を, LG は平等より
も公平を多く選択する傾向にあり，集団間が非友好的な 状況の LG では他の条件においてよりも公平を多く選 択する傾向にあったてとが見出された。

\section{考察}

分配公正の問題は，限られた資源とそれを必要とする 自己および他者の存在によって生じるものであり，すぐ れて対人関係的要素が重要之なる問題である。すなわち, 分配関して相互依存的な関係にある他者の存在とその 反応の予測とが個人の分配行動を大きく左右するといえ よう。

従来, 分配公正における他者への自己呈示に関する研 究では，他者への肯定的自己の呈示が，すなわち非利己 的選択を行なうことであるという図式から説明がなされ てきた。しかし，てのような説明がなされる前提として 非利己性を肯定的あるいは正しいとする価値観が存在し なくてはならない (Kahn, Lamm \& Nelson, 1977; Feather \& O'driscoll, 1980)。

ての視点からこてでは，まず集団内分配原理の選択に ついて，ついで集団間分配原理の選択について考察し， さらに集団間の要因が集団内の分配公正をどの上うに規 定するか，また逆に集団内の要因が集団間の分配公正を どのように規定するかについて総合的な考察を行ないた い。

\section{＜集団内分配原理の選択 $>$}

実験 I・実験 IIどちらにおいても，個人決定による 集団内分配原理の選択では一貫して高達成度の成員が平 等原理を，低達成度の成員が公平原理をそれぞれ選択し た。てれは，集団成員間の関係が友好的である集団では， 達成度において異なる成員間で相互に非利已的な選抧が なされたてとを示している。

一方集団決定による集団内分配原理の選択では，実験 II の低達成度集団以外の条件では公平原理よりも平等原 理が多く遙択された。てれは, 集団成員間関係が友好的 な場合には，集団内分配原理として平等が多く選択され たことを示している。さらに，集団内分配原理として平 等を選択した集団における, 決定への高達成度成員と低 達成度成員の影幚度についての自己評定では, 高達成度 の成員がより強い影響を与えたと認知していた。以上三 つの結果から，集団成員間が友好的な場合の分配原理の 選択では，まず高達成度の成員と低達成度の成員によっ て相互に非利已的な遙択が行なわれ，次いで高達成度の 成員による強い影響力によって平等原理が選択されると いう一連の分配原理選択過程が存在するであろうという 先の予測がほぼ支持されたと言えるであろう。集団間関 
係が非友好的な状況である実験 IIでの低達成度集団にお いて公平が多く選択されたてとについては，集団間要因 が集団内分配に影響を与えたてとが考えられるので，て の点については後述する。

\section{<集団間分配原理の選択>}

集団間関係が友好的な実験 I での個人決定による集団 間分配原理の選択においては, 平等原理が多く選択され た。乙れは集団間の関係が友好的な状況においては平等 原理が公正と思われるであろうという先の予測を支持し ている。また，集団決定による選択においても平等原理! が多く選択された。集団決定による選択は，相手集団 に対して呈示する自集団の選択であるから， Shapiro (1975) 以後の自己呈示に関する研究にそって考えるな らば，低達成度集団は利己的な選択を行ない高達成度集 団に対して肯定的な自集団の選択を呈示しなかったと言 えるであろう。

一方, 集団間関係が非友好的な実験 IIでの個人決定に よる選択においては実験 I とは逆に, 公平原理が多く選 択された。乙れも集団間の関係が非友好的な状況におい ては公平原理が公正と思われるであろうという先の予測 を支持している。また, 集団決定においては低達成度集 団は公平を多く選択し，個人決定による選択との一貫性 がみられたのに対し, 高達成度集団は平等を多く選択し 個人決定との一貫性がみられなかった。

高達成度集団が個人決定では公平を多く選択し, 他者 から見れば利己的な選択をした一方で，集団決定におい ては平等を多く選択したのは，他集団に対して非利己的 で肯定的な自集団の選択を呈示するよう動機づけられた ためと思われる。従って, 集団間関係が非友好的な状況 における集団決定では個人決定においてよりも非利已的 選択がなされるであろうという先の予測が，高達成度集 団において支持されたと言えるであろう。しかし低達成 度集団においては, 個人決定ですでに非利己的選択が行 なわれており, 集団決定でも一貫して非利已的選択が行 なわれ先の予測が支持されなかった。ての低達成度集団 の一貫した非利己的な公平原理選択については集団内分 配との関連で後述する。

\section{<偍団内分配と集団間分配との関連>}

集団内分配におよほす集団間要因の効果については集 団間の友好性之達成度によって集団内の凝集性に変化が 生じ, その結果, 集団内分配原理の選択涼晦をおよは すであろうという予測がなされた。しかし，本研究にお いてはてれらの集団間要因によって集団凝集性（集団成 員間の好意度の評定）に有意な差は見出されず，予測は 支持されなかった。とてろが, 集団内要因については各
条件に差がないにもかかわらず，集団間関係が非友好的 な実験II低達成度集団においては，他の条件とは異な り集団内分配原理として公平原理が平等原理よりを多く 選択されたてとから，なんらかの集団間要因が集団内分 配に影響を及ほしたと考えられる。すなわち実験 II の低 達成度集団は, 集団間分配原理の個人決定之集団決定に おいても一貫して公平原理を多く選択した。このてとは， 実験 II 低達成度集団が, 予測される集団間分配での高 達成度集団の反応（高達成度集団が公平をより好むだろ うと認知していた），および集団達成度における自集団 の劣勢によって, 集団間分配において公平原理が選択さ れるであろうと考え，集団内分配と集団間分配标ける 分配原理の選択に一貫性を持たせようとしたためと考え られる。また実験 I の高・低集団達成度条件においても 集団内，集団間分配原理の一貫した選択が見られたとと から, 本研究の上うに, 集団内, 集団間分配が相互依存 的な関係にある状況では，両者の間で一貫した分配原理 の選択が行なわれる傾向があり，てれが実験 Iの低達成 度集団の分配原理の選択涼影をおよぼしたものと考え られる。

しかし一方では実験 I の高達成度集団の個人決定のよ うに, 集団内分配原理の選択では達成度において異なる 成員が相互に非利已的選択をしたにもかかわらず，非友 好的な他集団との分配では利已的な分配原理の選択も見 られた。てれは，他集団に対しては利已的選択を行なう が自集団内では相互に非利己的選択を行なうという内集 団バイアス (ingroup bias) の効果 (Turner, 1978) が 集団間の非友好性によってさらに強められた結果による ものと考えられる。

とてろで本研究においては, 低達成度の成員と集団に よる公平原理選択の傾向が集団内, 集団間の分配を通し て見られたてとが特徽的であった。従来いくつかの研究 において低達成度成員による非利已的な公平原理の選択 が見出されてきたが明確な説明はなされていない（Shapiro, 1975; Curtis, 1979; 広瀬, 1977; 松崎他, 1980, 相川, 1981)。

本研究を含めて上記の諸研究においては, 実験者が被 験者集団に対して報酬を支払う際, 集団の達成度に応じ て報酬額の全部または一部を決定するという手続きが取 られてきたてとから，実験者が公平原理を公正としてい ろのであろうという推測が影響したと考えられる。いい かえれば, Lerner (1982) においても指摘があるように, 実験パラダイムそのものに公平原理を公正とする価值が 入っているため, 他者への自己呈示が被験者間で行なわ れるのみでなく実験者に対しても行なわれ，てれが達成 
度において異なる成員の分配原理選択を規定したものと 考えられる。すなわち, 実験者への肯定的な自己呈示は 高達成度成員にとっても，また低達成度成員にとっても 公平原理を選択することであるのに対し，集団内の他成 員への肯定的な自己呈示は高達成度成員にとっては平等 原理の選択であり，低達成度成員にとっては公平原理の 選択である。とのととは, 高達成度成員は自己呈示の対 象（実験者または低達成度成員のどちらか）を選択する ととによって公平原理と平等原理の選択が可能であるの に対し，低達成度成員は自己呈示の対象がどちらであっ ても公平原理の選択のみが可能であるてとを示している。 以上の上うに考えると低達成度成員が一貫して公平原理 を選択し, 高達成度成員が状況に応じて分配原理の選択 を行なったてとの説明ができると思われる。しかし，本 研究の知見からは, 実験者および実験パラダイムと被験 者の自己呈示との関連については明らかにされていない ので,これらの関連については今後の研究において明ら かにされるべきであろう。

本研究におけるその他の問題点としては, 集団間分配 における集団間討議による決定が行なえなかったてと， 集団成員間の関係において非友好的な条件の設定がなさ れなかったてと,および友好性の操作など, 実験操作上 の改良点があげられるであろう。これらの問題点につい ても今後の研究が必要と思われる。

\section{要約}

本研究は, 自集団以外の他集団と共に課題を遂行する 状況において，集団間の友好性と達成度の高低，集団成 員間の達成度の高低が, 集団内および集団間の報酬分配 の公正感をどのように規定するかを検討した。

集団間の関係が (1) 友好的である場合を実験 I， (2) 非友好的である場合を実験 II しし，各々の実験において 友人二人（個人達成度の高・低）加らる2 集団（集団 達成度の高低）に対し報酬を支払う相互传存的状況が設 定された。集団内分配と集団間分配において公平 (equity) と平等 (equality) の二つの分配原理につき, 個人 決定と集団決定の状況で分配原理の選択を行なわせた。

主な結果は以下の通りであった。

（1）個人決定による集団内分配原理の選択では，実 験 I ・実験 IIの両者において一貫して高達成度の成員が 平等原理を，低達成度の成員が公平原理を選択した。

（2）集団決定による集団内分配原理の選択において, 実験 IIの低達成度集団以外の条件では, 公平原理よりも 平等原理が多く選択され，また，平等原理を選択した集 団での集団決定に损いては高達成度の成員の強い影響力
があったととが見出された。

（3）個人決定による集団間分配原理の選択において は，実験 Iでは公平原理よりも平等原理が多く選択され， 逆に実験 IIでは平等原理よりも公平原理が多く選択され た。

（4）集団決定に上る集団間分配原理の選択において は, 実験 I では, 集団の達成度にかかわりなく平等原理 が多く選択され, 実験Iでは, 高達成度の集団は平等を 多く選択し，個人決定とは異なる選択をしたのに対し， 低達成度の集団は個人決定之同様公平原理を多く選执し た。

これらの結果については, 利己的・非利己的分配の観 点から考察され，特に，低達成度条件においてはそれが 個人であると集団であるとを問わず，非利己的分配原理 の選択を行なうものと考察された。

\section{引用文 献}

Adams, J. S. 1965 Inequity in social exchange. In Berkowitz, L. (Ed.), Advances in Experimental social Psychology, 2. New York: Academic Press.

相川 充 1981 報酬分配注ける個人決定と集団決定 について 心理学研究, 52, 113-119.

Commins \& Lockwood 1979 Social comparison and social inequality: An experimental investigation of intergroup behavior. British Journal of Social and Clinical Psychology, 18, 285-289.

Curtis, Rebecca C. 1979 Effects of knowledge of self-interest and social relationship upon the use of equity, utilitarian, and Rawlsian principles of allocation. European Jounal of Social Psychology, 9, 165-175.

Deutsch, M. 1975 Equity, equality, and need: What determines which value will be used as the basis of distributive justice? Journal of Social Issues, 31, 137-149.

Everitt, B.S. 1977 The analysis of contingency tables. Champman and Hall, B.S. エヴェリ ット著 山内光哉監訳, 弓野害一・菱谷晋介㰴 質的デー夕の解析, 1980, 新曜社

Feather \& O'Driscoll 1980 Observer's reactions to an equal or equitable allocator in reaction to allocator input, causal attributions, and value importance. European Journal of Social Psychology, 10, 107-129.

Greenberg, J. 1978 Equity, equality and the Protestant ethic: Allocating rewards following fair and unfair competition. Journal of Experimental Social Psychology, 14, 217226.

Greenberg, J. 1982 Countering inequity with ine- 
quity: Over-rewarding generosity and under-rewarding greed. European Journal of Social Psychology, 12, 181-185.

広瀨幸雄 1977 集団目標達成が地位分化並び亿報酬分 配に及ほす効果について 実験社会心理学研究, 17, 14-21.

Homans, G.C. 1961 Social behavior: Its elementary forms. Routledge Kegan Paul.

Kahn, Lamm, \& Nelson 1977 Preferences for an equal or equitable allocator. Journal of Personality and Social Psychology, 35, 837-844.

Kahn, Nelson, Gaeddert, \& Hearn 1982 The justice process: Deciding upon equity or equality. Social Psychology Quarterly, 45, 3-8.

Lamm \& Schwinger 1980 Norms concerning distributive justice: Are needs taken into consideration in allocation decisions? Social Psychology Quarterly, 43, 425-429.

Lerner, M. J. 1974 The justice motive: "Equity" and "parity" among children. Journal of Personality and Social Psychology, 29, 539-550.

Lerner, M. J. 1975 The justice motive in social behavior: Introduction. Journal of Social Issues, 31, 1-20.

Lerner, M. J. 1982 "The justice motive in human relations and the economic model of man: A radical analysis of facts and fictions", In Derlega \& Grzelak (Eds.) Cooperation and helping behavior: Theories and research. Academic Press, New York, 249-278.

Leventhal, G.S. 1976 The distribution of rewards and resources in groups and organizations, In Berkowitz, L. (Ed.) Advances in Experimental Social Psychology, 9. Academic Press, New York.

Leventhal, Michaels, \& Sanford 1972 Inequity and Interpersonal conflict: Reward allocation and secrecy about reward as methods of preventing conflict, Journal of Personality and Social Psychology, 23, 88-102.

松崎 学・相川 充・上野徳美 1980 報酬分配におけ る将来の相互作用への期待の効果一被分配者の存 在との関連において一 心理学研究, $51,120-$ 127.

Mikula, G. 1974 Nationality, performance, and sex as determinants of reward allocation. Journal of Personality and Social Psychology, 29, 435-440.
Morgan, W.R. \& Sawyer, J. 1967 Bargaining expectations and the preference for equality over equity. Journal of Personality and Social Psychology, 6, 139-149.

Rabbie, J. M., Benoist, F., Oosterbaan, H. \& Visser, L. 1974 Differential power and effects of expected competitive and cooperative intergroup interaction on intragroup and outgroup attitudes. Journal of Personality and Social Psychology, 30, 46-56.

Reis, H.T. \& Gruzen, J. 1976 On mediating equity, equality, and self-interest: The role of self-presentation in social exchange. Journal of Experimental Social Psychology, 12, 487-503.

Rosenbaum, M.E., Moore, D. L., Cotton, J.L., Cook, M. S., Hieser, R.A., Shovar, M.N. \& Gray, M. J. 1980 Group productivity and process: Pure and mixed reward structures and task interdependence. Jouroal of Personality and Social Psychology. 39, 626-642.

Sampson, E. E. 1975 On justice as equality. Journal of Social Issues, 31.

Shapiro, E. G. 1975 Effect of expectations of future interaction on reward allocation in dyads: Equity or equality. Journal of Personality and Social Psychology, 31, 873-880.

Sik Hung Ng 1981 Equity theory and the allocation of rewards between groups. European Journal of Social Psychology, 11, 439-443.

Turner, J. 1978 "Social categorization and social discrimination in the minimal group paradigm" pp. 101-140, In Tajfel, H. (Ed.), Differentiation between social groups: Studies in the psychology of intergroup relations, London, Academic Press.

Valentine, R. J. 1971 The effect of group unity on reward allocation behavior. Unpublished master's thesis, North Carolina State University, cited in Leventhal (1974).

Watts, B. L. \& Messé, L. A. 1982 The impact of task inputs, situational context, and sex on evaluations of reward allocators. Social Psy. chology Quarterly, 45, 254-262.

弓野憲一 1981 対数一線型モデルによる質的データの 解析とそのための BASIC プログラム 静岡大学 教育学部研究報告 (自然科学篇), 第32号 -1983 年 8 月 5 日 受稿一 


\title{
EFFECTS OF INTERGROUP RELATIONSHIPS AND LEVEL OF PERFORMANCE ON INTER - INTRA-GROUP REWARD DISTRIBUTION
}

\author{
JUN KUKITA \\ Kyushu University
}

The effects of intergroup relationships and individual and group performance on distributive justice in inter-and intragroup reward distribution were examined. Two experiments were done with (I) friendly and (II) unfriendly intergroup rela. tionships. A pair of dyads (with High and Low Group performance; HG, LG), each consisting of two friends (with High and Low Individual performance; $\mathrm{H}, \mathrm{L}$ ) was paid inproportion to their total performance. Subjects were asked to choose one of the two distribution principles (Equity or Equality) for intra- and inter-group reward distribution in indivudual and group dicision making situation. Major results were as follows. (a) Intragroup distribuion; $\mathrm{i}$ ) in the individual decision making situation, subjects with high performance chose the equality principle and subiects with low performance chose the equity principle, ii) in the group decision making situation, the equality priciple was chosen in each condition except for LG of Exp. I. (b) Intergroup distribution: i) in the individual dicision making situation, the equality principle was chosen more frequently than the equity principle in Exp. I and vice versa in Exp. II. ii) in the group dicision making situation, the equality principle was chosen in Exp. I, and in Exp. II the equality principle was chosen by LG. These results were discussed from the point of self-serving and non-self-serving distribution. It was concluded that individuals and groups are less self-serving in low performance condition.

key words : distributive justice, intergroup relationships, equity, equality, individual and group decision making, reward distribution, self-presentation. 